\title{
Rwanda is rising
}

\author{
David A. Fullerton, MD
}

\author{
From the Division of Cardiothoracic Surgery, The University of Colorado School of Medicine, Aurora, Colo. \\ Disclosures: Author has nothing to disclose with regard to commercial support. \\ Received for publication Nov 27, 2017; accepted for publication Dec 4, 2017; available ahead of print Jan 20, \\ 2018. \\ Address for reprints: David A. Fullerton, MD, Division of Cardiothoracic Surgery, University of Colorado School \\ of Medicine, 12632 E 17th Ave, MS C-310, Room 6602, Aurora, CO 80045 (E-mail: David.Fullerton@ \\ ucdenver.edu). \\ J Thorac Cardiovasc Surg 2018;155:2553 \\ $0022-5223 / \$ 36.00$ \\ Copyright (C) 2018 Published by Elsevier Inc. on behalf of The American Association for Thoracic Surgery \\ https://doi.org/10.1016/j.jtcvs.2017.12.011
}

The economic growth of any country is directly related to the health and well-being of its people. Because the health and well-being of low-income countries is poor, the populations of these countries die premature deaths, leaving the countries without a robust and productive workforce. The result is a vicious cycle of poverty and disease. Within the next decade, the leading causes of death in low-income countries will be diseases of the chest. Most of these diseases are surgically treatable diseases. As a result, the demand for cardiothoracic surgical programs in low-income countries will grow significantly. In their report in this issue of the Journal, Bolman and colleagues ${ }^{1}$ have provided a template for the development of a sustainable cardiac surgical program in such a country.

Bolman and colleagues ${ }^{1}$ began their work in Rwanda a mere decade after genocide had nearly destroyed the country. At that time, the country was a pariah on the world stage and was among the poorest in the world. Its people had little hope. Today, Rwanda clearly has a brighter economic future, which results in part from the significant improvement of the health of its people. Remarkably, there has been nearly a $50 \%$ decline in premature death from cardiovascular disease in Rwanda between the years 1990 and 2013. Bolman and colleagues ${ }^{1}$ deserve great credit for leading the way in the treatment of cardiac disease in this country.

Despite significant challenges, they have achieved excellent surgical results. Their report emphasizes the importance of rigorous patient selection and the value of cognizance of the limitations of their resources. Their success also exemplifies the need for such surgical groups to

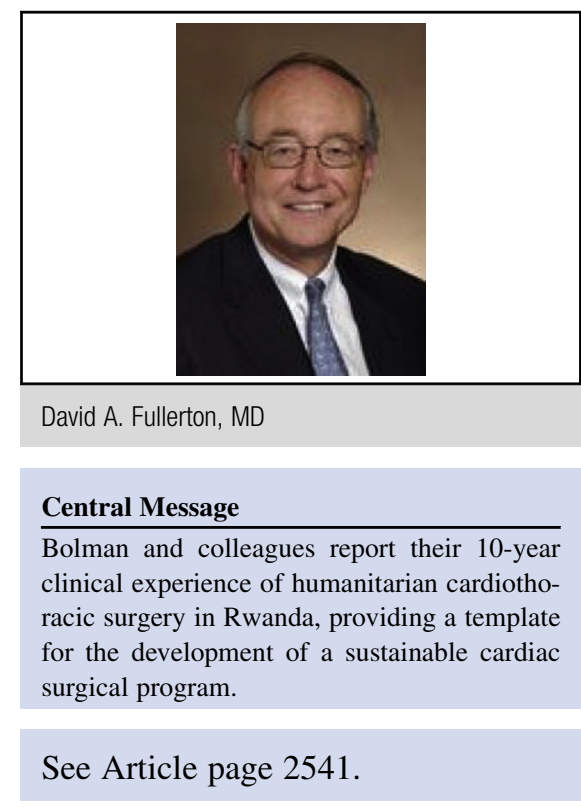

respect the cultural and political differences of a host country.

From the outset, among the most important objectives of Bolman and colleagues ${ }^{1}$ were to establish a long-term relationship with people of Rwanda and to create a selfsustaining mechanism for the provision of cardiovascular care. They made a commitment to the creation of a durable program, and they were successful. A new, state-of-the-art hospital will soon be built, and plans are being finalized for the cardiothoracic surgical training of Rwandans who will care for their population. Rwanda is rising, and it is foreseeable that during the next decade, Rwanda - of all placeswill be a beacon of health care success in sub-Saharan Africa.

There is much to learn from and to admire about the experiences of Bolman and colleagues. ${ }^{1}$ They are to be congratulated for demonstrating not only what can be done, but how to do it.

\section{Reference}

1. Swain JD, Sinnott C, Suellen B, Charles RH, Mody G, Nyirimanzi N, et al. Tenyear clinical experience of humanitarian cardiothoracic surgery in Rwanda: Building a platform for ultimate sustainability in a resource-limited setting. J Thorac Cardiovasc Surg. 2018;155:2541-50. 